\title{
Relation of Water Temperature to Infection of Salmo gairdneri with Motile Aeromonas
}

\author{
Teresa P. Nieto*1 , M. J. R. CoRCOBADo*1, Alicia E. ToRAnZO*2, \\ and Juan L. BARJA*2 \\ ${ }^{* 1}$ Departamento de Microbiología, Colegio Universitario de Orense, \\ Universidad de Santiago de Compostela, Spain \\ *2 Departamento de Microbiología, Facultad de Biologia, \\ Universidad de Santiago de Compostela, Spain
}

\begin{abstract}
We have studied two epizootic outbreaks occurred in March, 1983 and April, 1984, in fingerling rainbow trout of about $4 \mathrm{~cm}$ length reared in freshwater at North-West of Spain. A total of 84 strains were isolated from peritoneal cavity, liver, kidney and gills of diseased fish and were assigned to five main bacterial groups: Aeromonas, Flavobacterium-Cytophaga, Pseudomonas-Xanthomonas, Gram positive Cocci and Enterobacteria. All these bacterial groups were present in the peritoneal cavity, kidney and gills, whereas Pseudomonas-Xanthomonas and Gram (+) Cocci were not recovered from liver. Aeromonas $(50 \%)$ and Flavobacterium-Cytophaga $(15.6 \%)$ were the prevalent groups in the peritoneal cavity, being also detected in high percentage in kidney and gills. The majority of the Aeromonas strains belonged to the motile Aeromonas group, and were further classified to the species level.

Most of the Aeromonas strains resulted to be pathogenic for rainbow trout. Four representative strains were tested for $\mathrm{LD}_{50}$ values and included in the "virulent" $\left(\mathrm{LD}_{50} \leq 10^{4.5}\right)$ or "weakly virulent" $\left(\mathrm{LD}_{50}=10^{5.5}\right)$ categories. These strains produced gas from glucose, were VP positive and fermented salicine, being assigned to the $A$. hydrophila species, and three of them shared the characteristics of the ideal phenotype of $A$. hydrophila biovar hydrophila displaying a strong. elastase and staphylolytic activities.

The analysis of physico-chemical and bacteriological parameters of the water, revealed that both epizootics appeared to be "stress" mediated since the mortalities occurred when the temperature of water suddenly increased from $5.5-8^{\circ} \mathrm{C}$ to more than $11^{\circ} \mathrm{C}$. Then, our data confirm that motile Aeromonas septicemia is usually enhanced by elevations of water temperature.
\end{abstract}

\section{Introduction}

Motile Aeromonas septicemia is a common bacterial disease syndrome in cultured and reservoir fish populations (Boulanger et al., 1977; De Figueiredo and Plumb, 1977; LaRsen and JeNSEN, 1977). Aeromonas species are widely distributed in nature, being considered autochthonous inhabitants of aquatic environments (HAZEN et al., 1978; SEIDLER et al., 1980; LARSEN and WILLEBERG, 1984) and they comprise a portion of the normal microbial flora of apparently healthy fishes (TRUST and Sparrow, 1974; SaKata et al., 1980; NiEto et al., 1984; TORANZo et al., 1985).

Aeromonas hydrophila is one of the main opportunistic fish pathogens which under environmental or physiological stress can produce epizootic outbreaks (Haley et al., 1967; Fliermans et al., 1977;
Groberg et al., 1978). In addition, it has long been also considered as a pathogen in Amphibians, reptiles, snails (SHOTTs et al., 1972; RIGNEY et al., 1978), and more recently has received particular attention because its association with human disease (DAvis et al., 1978; JosePH et al., 1979).

At present, the taxonomy of Aeromonas spp. is confused, and it has been demonstrated that a great variation in virulence exists within the motile Aeromonas isolated from fishes (De FigUEIREDO and Plumb, 1977; Mittal et al., 1980; WaKabayashi $e t$ al., 1981). Then, it is apparently not clear at this time whether A. hydrophila or A. sobria has more virulent characteristcs (OLIVIER et al., 1981; WAKABAYASHI et al., 1981; Hsu et al., 1981).

A number of extracellular virulence factors, including proteases, enterotoxins, cytotoxins and hemolysins, have been associated with the patho- 
Table 1. Total numbers of fish sampled during the epizootics

\begin{tabular}{ccccc}
\hline \hline Date & $\begin{array}{c}\text { Total fish } \\
\text { sampled }\end{array}$ & $\begin{array}{c}\text { Moribund fish } \\
\text { (with clinical signs) }\end{array}$ & Dead fish & $\begin{array}{c}\text { Apparently } \\
\text { healthy fish }\end{array}$ \\
\hline March, 1983 & 32 & 10 & 8 & 14 \\
April, 1984 & 31 & 8 & 8 & 15 \\
\hline
\end{tabular}

genesis of Aeromonas, but their role in the fish disease requires further assessment (Allan and SteVenson, 1981; Thune et al., 1982; LALlier et al., 1984). The present study was conducted to provide more information about the role of the temperature in the origin of epizootic outbreaks in cultured rainbow trout (Salmo gairdneri) carrying motile Aeromonas.

\section{Materials and Methods}

\section{Collection of Samples and Ambiental Conditions}

We have followed two epizootic outbreaks that occurred during March, 1983 and April, 1984, in fingerling rainbow trout reared in a freshwater hatchery located at North-West of Spain.

Mortalities reached a maximum of $20 \%$ mainly in fingerlings of about $4 \mathrm{~cm}$ length. There was not noticeable mortalities in adult fish.

The clinical signs observed in some diseased rainbow trout involved swelling of the body cavity and hemorrhaging in the internal organs, which sporadically showed petechiae. However, mortalities occurred most frequently without external symptons.

We sampled moribund or recently dead fish taken from different tanks, which presented the highest rate of mortality. For comparative purposes we also analyzed apparently healthy rainbow trout. Total numbers of fish examined during each epizootic are shown in Table. 1. During these studies, a group of healthy fish were maintained in the laboratory with water of the hatchery, to observe their posterior evolution.

Samples of the water supply were collected before it entered into the fish tanks, to study the physicochemical and bacteriological parameters that could adversely affect to the fish, being a cause of "stress".

Temperature (degrees Celsius), dissolved Oxygen $(\mathrm{mg} / \mathrm{l}$ ) and $\mathrm{pH}$, were monitored along this study using a portable electrode (YSU-57, Yellow Spring Inst. USA).
The bacteriological quality of the river water was assessed by determining the Total Viable Count (TVC) of heterothrophic mesophilic bacteria on TSA at $20^{\circ} \mathrm{C}$ for $48 \mathrm{hr}$, as well as the total Coliforms (TC) and Faecal Streptococci (FS) by the Most Probable Number (MPN) method following the procedures of The American Public Health Association (APHA, 1980).

\section{Bacterial Isolation and Biochemical Characteristics}

Samples from liver, kidney, peritoneal cavity and gills were taken under aseptic conditions, and streaked directly onto plates of Trypticase-SoyAgar (TSA) (Difco). After $48 \mathrm{hr}$ incubation at $25^{\circ} \mathrm{C}$, a representative number of the most numerous colony types from all samples were picked off from the inoculated plates, subcultured repeatedly until pure and stored on TSA slants under mineral oil.

All the bacterial isolates were subjected to taxonomic analysis by examination of their morphological, physiological and biochemical characteristics as previously described (NiETo et al., 1984), and final identification was based in the schemes proposed by McDaniel (1979) and Popoff (1984).

The biochemical profiles of the presumptive Aeromonas strains were confirmed using the API 20E system (Analytab Products), and results were compared with those obtained in the conventional tube tests. The multitest medium devised by KAPER et al. (1979) for identification of $A$. hydrophila (AH medium) was also utilized.

Additional tests as fermentation of salicine, production of gas from glucose and $\mathrm{SH}_{2}$ from cysteine, hemolysis, elastase and staphylolysis, were also performed as important differential traits within the motile Aeromonas group. Elastase activity was determined according to the modified medium of Hsu et al. (1981) which allow to reduce the incubation time to $72 \mathrm{hr}$. The staphylolysis test was carried out in TSA plates using Staphylococcus aureus strain ATCC 25923. 
A. hydrophila Reference strain ATCC 7966 and strain No. 67-P-24 (isolated from Plecoglossus altivelis in Japan), were used as controls in the biochemical tests conducted.

\section{Virulence Tests}

To define levels of virulence among the bacterial isolates, pathogenicity assays were basically conducted as previously described (Toranzo et al., 1983) using fingerling rainbow trout with an average weight of $10 \mathrm{~g}$.

Pure cultures of a representative number of strains from each bacterial group, were grown overnight in TSB at $20^{\circ} \mathrm{C}$. Logarithmic-phase cultures were centrifuged, and the cells resuspended in Ringer solution. Bacterial concentrations in the inocula were adjusted to contain $10^{8}$ cells $/ \mathrm{m} /$ by measure of the optical density at $540 \mathrm{~nm}$, and viable bacteria numbers were estimated by the standard plate count method on TSA. Fish were inoculated intraperitoneally with $0.1 \mathrm{~m} /$ of the corresponding suspension of each bacterial strain (15 fish were inoculated per strain), and were maintained in freshwater aquariums with a temperature range of 16 to $20^{\circ} \mathrm{C}$. Mortalities were recorded daily for a two weeks period, and were considered to be due to the inoculated strain only if bacteria could be recovered as pure cultures from the internal organs of dead fish.

A group of Aeromonas strains of high virulence according to the criteria of WAKABAYASHI et al. (1981) $(100 \%$ mortality in seven days), were further tested in order to determine the degree of virulence expressed as $\mathrm{LD}_{50}(50 \%$ Lethal Dose). Fingerling rainbow trout were inoculated with $0.1 \mathrm{~m} l$ of tenfold dilution of each bacterial suspension, ranging from $10^{2}$ to $10^{7}$ cells $/ \mathrm{ml}$ ( 5 to 8 fish were used per dose). The mean $\mathrm{LD}_{50}$ values were determined after seven days by the REED and MUENCH method (1938).

\section{Results}

The physico-chemical and bacteriological parameters of the water supply at the start of each epizootic outbreak are shown in Table 2. The $\mathrm{pH}$ was slightly acid and the dissolved oxygen was near saturation. Only the water temperature suffered in both epizootics a sudden elevation. So, during the winter the temperature ranged between 5.5 and $8^{\circ} \mathrm{C}$, but in March, 1983 (first epizootic) and in

Table 2. Physico-chemical and bacteriological parameters of the water supply at the start of each epizootic outbreak

\begin{tabular}{lcccccc}
\hline \hline Date & $\begin{array}{c}\text { Temperature } \\
\left({ }^{\circ} \mathrm{C}\right)\end{array}$ & $\mathrm{pH}$ & $\begin{array}{c}\text { Disolved oxygen } \\
(\mathrm{mg} / \mathrm{m} l)\end{array}$ & TVC/ml & TC & FS \\
\hline March, 1983 & 11 & 6.6 & 9.0 & 300 & 15 & 23 \\
April, 1984 & 12 & 6.4 & 8.5 & 350 & 23 & 9 \\
\hline
\end{tabular}

TVC, Total Viable Count on tryptic-soy-agar.

TC, Total Coliforms $/ 100 \mathrm{~m} l$.

FS, Faecal Streptococci/ $100 \mathrm{~m} l$.

Table 3. Percentage of strains isolated from diseased rainbow trout in the epizootic outbreaks

\begin{tabular}{lcccc}
\hline \hline \multicolumn{1}{c}{ Bacterial groups } & Peritoneal cavity & Liver & Kidney & Gills \\
\hline Aeromonas & 50 & 44 & 23 & 21 \\
Flavobacterium-Cytophaga & 15.6 & 44 & 15.4 & 28 \\
Pseudomonas-Xanthomonas & 9.3 & - & 23 & 21 \\
Gram (+) Cocci & 12.5 & 12 & 30.7 & 7.1 \\
Enterobacteria & 12.5 & 25 & 13 & 14.2 \\
\hline Total number of isolates & 32 & & 14 \\
\hline
\end{tabular}


April, 1984 (second epizootic), reached values of $11^{\circ} \mathrm{C}$ and $12{ }^{\circ} \mathrm{C}$, respectively. After these rapid shifts, the temperature increased progressively until a maximum in August. The bacteriological param- eters of water quality were within the normal values for a clean river.

A total of 84 strains were isolated from either moribund or recently dead fish, and were assigned

Table 4. Biochemical characteristics and virulence degree of selected Aeromonas strains isolated from diseased rainbow trout

\begin{tabular}{|c|c|c|c|c|c|c|}
\hline \multirow{3}{*}{ Characteristics } & \multicolumn{6}{|c|}{ Aeromonas strains } \\
\hline & \multicolumn{2}{|c|}{ Collection strains } & \multicolumn{4}{|c|}{ Present study } \\
\hline & ATCC 7966 & $67-P-24$ & $\mathrm{~T}-12$ & $\mathrm{~T}-16$ & $\mathrm{~T}-80$ & $\mathrm{~T}-2$ \\
\hline Gram stain & - & - & - & - & - & - \\
\hline Motility & + & + & + & + & + & + \\
\hline Oxidase & + & + & $t$ & + & + & + \\
\hline Catalase & + & + & + & + & + & + \\
\hline Nitrate reduction & + & + & + & + & + & + \\
\hline Growth on TCBS-agar & $(+)^{a}$ & - & - & - & - & - \\
\hline Growth on McConKey-agar & + & + & + & + & + & + \\
\hline Growth on SS-agar & + & + & + & + & + & + \\
\hline Sensitivity to $0 / 129(150 \mu \mathrm{g})$ & $\mathrm{R}^{\mathrm{b}}$ & $\mathbf{R}$ & $\mathrm{R}$ & $\mathrm{R}$ & $\mathbf{R}$ & $\mathrm{R}$ \\
\hline$\beta$-Galactosidase & + & + & + & + & + & + \\
\hline Arginine dihydrolase & + & + & + & + & + & + \\
\hline Lysine decarboxylase & - & $(+)$ & - & $(+)$ & - & $(+)$ \\
\hline Ornithine decarboxylase & - & - & - & - & - & - \\
\hline Citrate & - & + & + & + & + & + \\
\hline $\mathrm{H}_{2} \mathrm{~S}$ from tiosulphate & - & - & - & - & - & - \\
\hline Urease & - & - & - & - & - & - \\
\hline Tryptophane deaminase & - & - & - & - & - & - \\
\hline Indole & + & + & + & + & + & + \\
\hline Voges-Proskauer & + & + & + & + & + & + \\
\hline Gelatinase & + & + & + & + & + & + \\
\hline Fermentation of glucose & + & + & + & + & + & + \\
\hline Fermentation of mannitol & + & + & + & + & + & + \\
\hline Fermentation of inositol & - & - & - & - & - & - \\
\hline Fermentation of sorbitol & - & - & - & + & - & - \\
\hline Fermentation of rhamnose & - & - & + & + & - & - \\
\hline Fermentation of sucrose & + & + & + & + & + & + \\
\hline Fermentation of melibiose & - & - & - & - & - & - \\
\hline Fermentation of amygdalin & - & + & + & + & + & + \\
\hline Fermentation of arabinose & + & + & + & + & + & - \\
\hline Fermentation of salicine & + & + & + & + & + & + \\
\hline Gas from glucose $\left(25^{\circ} \mathrm{C}\right)$ & + & + & + & + & + & + \\
\hline $\mathrm{H}_{2} \mathrm{~S}$ from cysteine & $(+)$ & + & + & + & + & + \\
\hline Elastase production $(72 \mathrm{~h})$ & - & + & + & + & + & - \\
\hline Staphylolysis & - & + & + & + & + & - \\
\hline Hemolysis (sheep erythrocytes) & + & + & + & + & + & + \\
\hline Virulence $\left(\mathrm{LD}_{50}\right)^{\mathrm{d}}$ & $\mathrm{ND}^{\mathrm{c}}$ & ND & $10^{5.5}$ & $10^{4.5}$ & $10^{4.3}$ & $10^{5.6}$ \\
\hline
\end{tabular}

a $(+)$, weak or delayed positive reactions.

b $\mathrm{R}$, resistant strain.

c ND, not determined.

d $\mathrm{LD}_{50}=$ Number of bacteria needed to kill $50 \%$ of the inoculated fish in a 7 -day period. 
to five bacterial groups: Aeromonas, Flavobacterium-Cytophaga, Pseudomonas-Xanthomonas, Gram positive Cocci and Enterobacteria. The percentage of strains belonging to each bacterial group within the fish organs studied, are shown in Table 3. All the bacterial groups were present in the peritoneal cavity, being Aeromonas (50\%) and Flavobacterium-Cytophaga $(15.6 \%)$ the prevalent groups. These genera predominated also in the liver, whereas Pseudomonas-Xanthomonas and Gram (+) Cocci were not recovered from this organ. Although we have detected in high percentage four of the five bacterial groups present in the kidney, the number of isolates from this organ was shorter than in the other organs sampled. We can not rule out that the presence of Gram $(+)$ Cocci in peritoneal cavity, kidney and gills was due to the handling or contaminated fish food.

We focused our further studies on the characterization of Aeromonas strains, since was the only group found in high percentage in all organs from all the fish examined. The majority of the isolates were identified as motile Aeromonas based on the following characteristics: Gram-negative rods, motile, oxidase and catalase positive, glucose fermentative, $\beta$-galactosidase positive, nitrate positive, indole positive, arginine dihydrolase positive, ornithine decarboxylase negative, mannitol positive, inositol negative, resistant to the vibriostatic agent $0 / 129$ and Novobiocin.

The results of virulence tests demonstrated that most of the Aeromonas strains fell in the categories of "high virulence" or "low virulence", as defined by WAKABAYASHI et al., (1981), because they produced in a preliminary screening, mortalities between $70 \%$ and $100 \%$ of the inoculated fish with a bacterial dose of $10^{7}$ cells. Some strains of high virulence were further tested for $\mathrm{LD}_{50}$ values. Table 4 shows the biochemical characteristics as well as the virulence degree of four representative pathogenic motile Aeromonas, in comparison with control A. hydrophila strains.

Our Aeromonas strains were classified to the species level according to the POPOFF and VERON schemes (1976), taken as important differential traits production of gas from glucose, fermentation of salicine and arabinose, Voges-Proskauer reaction and elastase production. Three strains (T-12 and T16 isolated from gills and $\mathrm{T}-80$ from liver) share the characteristics of the ideal phenotype of $A$. hydrophila biovar hydrophila, similarly to the control strain 67-P-24. The strain T-2 isolated from peritoneal cavity, although did not ferment arabinose and was elastase negative, was also assigned to the A. hydrophila species (as defined by SCHUBERT, 1974).

According to the degrees of virulence described by LALLIER et al. (1981), two strains were included in the "virulent category" because displayed a mean Lethal Dose $\leq 10^{4.5}$, whereas the other two Aeromonas tested (Table 4) belonged to the level of "weakly virulent" $\left(\mathrm{LD}_{50} \simeq 10^{5.5}\right)$.

\section{Discussion}

Until recently, the few attempts made to correlate the biochemical characteristics of $A$. hydrophila with production of extracellular virulence factors have been practically conducted with clinical or environmental strains. So, BurKe et al. (1982 and 1984) studying the biochemical properties of motile Aeromonas isolated from different environmental sources, found that most of the strains displaying enterotoxic and hemolytic activities produced gas from glucose, were Voges-Proskauer positive, and did not ferment arabinose which, as defined by SCHUBERT (1974), should correspond to $A$. hydrophila subsp. hydrophila. However, if we consider the simplified classification of POPOFF and VÉrON (1976) and Popoff (1984), these strains could be included either in $A$. hydrophila or $A$. sobria species.

A correlation between cytotoxin production and the presence of a positive VP phenotype was also reported by Cumberbach et al. (1979) in clinical isolates of $A$. hydrophila.

Similarly to the findings of these authors, in our study the four characterized pathogenic Aeromonas strains (Table 4), shared together with the control strains, the characteristics of to produce gas from glucose and to be VP positive.

There are several reports that show the $A$. $h y$ drophila described by POPOFF and VÉRON (1976) to be more virulent than $A$. sobria (Boulanger et al., 1977; Mittal et al., 1980). However, both of these proposed species are potentially virulent with regard to enterotoxigenicity (SEIDLER et al., 1980). By the other hand, the results of WAKABAYASH et al. (1981) and Hsu et al. (1981), show that if motile Aeromonas isolated from fishes possess a high elastase or staphylolytic activity, they will usually be 
virulent strains.

In the present study, three pathogenic Aeromonas (T-12, T-16 and T-80) displayed a strong elastase and staphylolytic activities, similarly to the Japanese $A$. hydrophila 67-P-24. In addition, our Aeromonas as well as the control strains produced hemolysins (Table 4). Recent studies of BURKE et al. (1982 and 1984) and RAHIM et al. (1984), demonstrated that hemolysin production correlates closely with enterotoxigenicity in $A$. hydrophila isolated from water and fish skin. Then, these strains can represent a potential public health hazard.

The mechanism of pathogenicity of Aeromonas for fish has not been clearly identified. Whereas THUNE et al. (1982), obtained a toxic fraction for fish with proteolytic but no hemolytic activity, Allan and STEVEnson (1981), considered the hemolytic activity as a significant toxic factor for fish. Unfortunately, until now, the biological activities of Aeromonas products have been defined in terms of their effects on mammalian cells and systems, even when the disease process occurs in fish or other poiquilotherm animals.

The analysis of the physico-chemical and bacteriological parameters of the water during the two epizootic outbreaks, seems to indicate that the disease was "stress" mediated, since in both cases the mortalities of rainbow trout occurred in late winter and spring when the water temperature suddenly increased to more than $11^{\circ} \mathrm{C}$ (Table 2). The relationship of water temperature with numbers of fish-infections induced by $A$. hydrophila has also been reported (FLIERmans et al., 1977; Groberg et al., 1978). That is, Groberg et al. (1978), found than fatal experimental infections with $A$. hydrophila in juvenile steelhead trout, chinook salmon and coho salmon, were progressively enhanced as the temperature was increased from $12^{\circ} \mathrm{C}$, and were suppressed at $9^{\circ} \mathrm{C}$ and below. In addition, temperatures of $15-20^{\circ} \mathrm{C}$, which gave the highest "in vitro" growth rates of $A$. hydrophila, were also those that displayed the greatest fish mortalities in the shortest time period.

Interestingly, during these epizootics we have isolated certain Pseudomonas and Enterobacteria which also proved to be virulent strains. Then, we can not rule out the possibility that some fish had a mixed bacterial infection involving mainly motile Aeromonas.

Actually, we are conducting more extensive studies (using both homeotherm and poiquilotherm cell-systems) in order to a better understanding of the relationships between the biotype and virulence characteristics of Aeromonas species isolated from diseased and healthy fishes, which will allow us a more adequate classification of these strains in relation to their role in the production of disease.

\section{References}

Allan, B. J. and R. M. W. Stevenson (1981): Extracellular virulence factors of Aeromonas hydrophila in fish infections. Can. J. Microbiol., 27, 1114-1122.

American Public Health Association (APHA) (1980): Standard Methods for the Examination of Water and Wastewater. 15th ed., American Public Health Association, Inc., Washington D.C., pp. 747-829.

Boulanger, Y., R. Lallier, and G. Cousineau (1977): Isolation of enterotoxigenic Aeromonas from fish. Can. J. Microbiol., 23, 1161-1164.

Burke, V., J. Robinson, H. AtKinson, and M. Gracey (1982): Biochemical characteristics of enterotoxigenic Aeromonas spp. J. Clin. Microbiol., 15, 48-52.

Burke, V., J. Robinson, M. Cooper, J. Beaman, K. Partridge, D. Peterson, and M. Gracey (1984): Biotyping and virulence factors in clinical and environmental isolates of Aeromonas species. Appl. Environ. Microbiol., 47, 1146-1149.

Cumberbatch, N., M. J. Gurwith, C. Langston, R. B. SACK, and J. L. Brunton (1979): Cytotoxic enterotoxin produced by Aeromonas hydrophila: relationship of toxigenic isolates to diarrheal disease. Infect. Immun., 23, 829-837.

Davis, W. A., J. G. Kane, and V. P. Garagusi (1978): Human Aeromonas infections a review of the literature and a case of endocarditis. Medicine, 57, 267-277.

De Figueiredo, J. and J. A. Plumb (1977): Virulence of different isolates of Aeromonas hydrophila in channel catfish. Aquaculture, 11, 349-354.

Fliermans, C. B., R. W. Gorden, T. C. Hazen, and G. W. Esch (1977): Aeromonas distribution and survival in a thermally altered lake. Appl. Environ. Microbiol., 33, 114-122.

Groberg, W. J., R. H. McCoy, K. S. Pilcher, and J. L. FrYer (1978): Relation of water temperature to infections of coho salmon (Oncorhynchus kisutch), chinook salmon (O. tshawytscha), and steelhead trout (Salmo gairdneri) with Aeromonas salmonicida and $A$. hydrophila. J. Fish. Res. Board Can., 35, 1-7.

Haley, R., S. P. Davis, and J. M. Hide (1967): Environmental stress and Aeromonas liquefaciens in American and threadfin shad mortalities. Prog. Fish Cult., 29, 193.

Hazen, T. C., C. B. Fliermans, R. P. Hirsch, and G. W. EsCH (1978): Prevalence and distribution of Aeromonas hydrophila in the United States. Appl. Environ. 
Microbiol., 36, 731-738.

Hsu, T. C. W. B. Waltman, and E. B. Shotts (1981): Correlation of extracellular enzymatic activity and biochemical characteristics with regard to virulence of Aeromonas hydrophila. Develop. biol. Standard., 49, 101-111.

Joseph, S. W., O. P. Daily, W. S. Hunt, R. J. Seidler, D. A. Allen, and R. R. Colwell (1979): Aeromonas primary wound infection of a diver in polluted waters. $J$. Clin. Microbiol., 10, 46-49.

Kaper, J. B., R. J. Seidler, H. Lockman, and R. R. Colwell (1979): Medium for the presumptive identifcation of Aeromonas hydrophila and Enterobacteriaceae. Appl. Environ. Microbiol., 38, 1023-1026.

Lallier, R., K. R. Mittal, D. Leblanc, G. Lalonde and G. OlivieR (1981): Rapid methods for the differentiation of virulent and non-virulent Aeromonas hydrophila strains. Develop. biol. Standard., 49, 119-123.

Lallier, R., F. Bernard, and G. Lalonde (1984): Difference in the extracellular products of two strains of Aeromonas hydrophila virulent and weakly virulent for fish. Can. J. Microbiol., 30, 900-904.

Larsen, J. L. and N. J. Jensen (1977): An Aeromonas species implicated in ulcer-disease of the cod (Gadus morhua). Nord. Vet. Med., 29, 199-211.

Larsen, J. L. and P. Willeberg (1984): The impact of terrestrial and estuarial factors on the density of environmental bacteria (Vibrionaceae) and faecal coliforms in coastal water. Zbl. Bakt. Hyg., I. Abt. Orig., B179, 308-323.

McDaniel, D. (1979): Fish Health Blue Book. "Procedures for the detection and identification of certain fish pathogens" American Fisheries Society. Washington, D.C.

Mittal, K. R., G. Lalonde, D. Leblanc, G. Olivier, and R. LALliER (1980): Aeromonas hydrophila in rainbow trout: relation between virulence and surface characteristics. Can. J. Microbiol., 26, 1501-1503.

Nieto, T. P., A. E. Toranzo, and J. L. Barja (1984): Comparison between the bacterial flora associated with fingerling rainbow trout cultured in two different hatcheries in the North-West of Spain. Aquaculture, 42, 193-206.

Olivier, G., R. LALlier, and S. LARIVIÈre (1981): Toxigenic profile of Aeromonas hydrophila and Aeromonas sobria isolated from fish. Can. J. Microbiol., 26, 330-333.

Popoff, M. and M. VÉron (1976): A taxonomic study of the Aeromonas hydrophila-Aeromonas punctata group. J. Gen. Microbiol., 94, 11-22.

Popoff, M. (1984): Genus III Aeromonas. p. 545-548. In J. G. Holt and N. R. Krieg (eds.), Bergey's Manual of Systematic Bacteriology, 9th ed., The Williams and Wilkins Co., Baltimore.

Rahim, Z., S. C. Sanyal, K. M. S. Aziz, M. I. HuQ, and A. A. Chowdhury (1984): Isolation of enterotoxigenic, hemolytic, and antibiotic-resistant Aeromonas hydrophila strains from infected fish in Bangladesh. Appl. Environ. Microbiol., 48, 865-867.

REED, L. J. and H. MUENCH (1938): A simple method of estimating fifty percent end points. Am. J. Hyg., 27, 493-497.

Rigney, M. M., J. W. Zilinsky, and M. A. Rouf (1978): Pathogenicity of Aeromonas hydrophila in red-leg disease in frogs. Curr. Microbiol., 1, 175-179.

SaKata, T., J. OKabayashi, and D. Kakimoto (1980): Variations in the intestinal microflora of tilapia reared in fresh and sea water. Bull. Jpn. Soc. Sci. Fish., 46, 967975.

Schubert, R. H. W. (1974): Genus II. Aeromonas. p. 345-348. In R. E. Buchanan and Gibbons (eds.), Bergey's Manual of Determinative Bacteriology, 8th ed., The Williams and Wilkins Co., Baltimore.

Seidler, R. J., D. A. Allen, H. Lockman, R. R. Colwell, S. W. Joseph, and O. P. Daily (1980): Isolation, enumeration and characterization of Aeromonas from polluted waters encountered in diving operations. Appl. Environ. Microbiol., 39, 1010-1018.

Shotts, E. B., J. L. Gaines, C. Martin, and A. K. PRESTWOOD (1972): Aeromonas-induced deaths among fish and reptiles in an eutrophic inland lake. J. Am. Vet. Med. Assoc., 161, 603-607.

Thune, R. L., T. E. Graham, L. M. Riddle, and R. L. AMBORSKI (1982): Extracellular products and endotoxin from Aeromonas hydrophila: effects on age-0 channel catfish. Trans. Am. Fish. Soc., 111, 749-754.

Toranzo, A. E., J. L. Barja, S. A. Potter, R. R. Colwell, F. M. Hetrick, and J. H. Crosa (1983): Molecular factors associated with virulence of marine vibrios isolated from striped bass in Chesapeake Bay. Infect. Immun., 30, 1220-1227.

Toranzo, A. E., P. Combarro, Y. Conde, and J. L. Barja (1985): Bacteria isolated from rainbow trout reared in fresh water in Galicia (Northwestern Spain): Taxonomic analysis and drug resistance patterns. In "Fish and Shellfish Pathology" (A. E. Ellis, ed.) Chap. 15, p. 141-152.

Trust, T. J. and R. A. H. Sparrow (1974): The bacterial flora in the alimentary tract of freshwater salmonid fishes. Can. J. Microbiol., 20, 1219-1228.

Wakabayashi, H., K. Kanal, T. C. Hsu, and S. Egusa (1981): Pathogenic activities of Aeromonas hydrophila biovar hydrophila (Chester) POPOFF and VÉroN, 1976 to fishes. Fish Pathol., 15, 319-325. 